\title{
Morphometric analysis of active normal faulting in slow-deformation areas : examples in the Lower Rhine Embayment
}

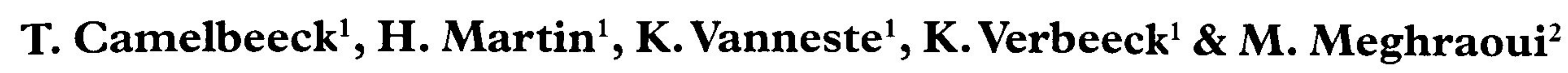

1 Royal Observatory of Belgium, avenue circulaire 3, B-1180 Bruxelles; e-mail: thierry.camelbeeck@oma.be

${ }^{2}$ EOST, Institut de Physique du Globe, rue René Descartes 5, F-67084 Strasbourg

Manuscript received: July 2000; accepted: April 2001

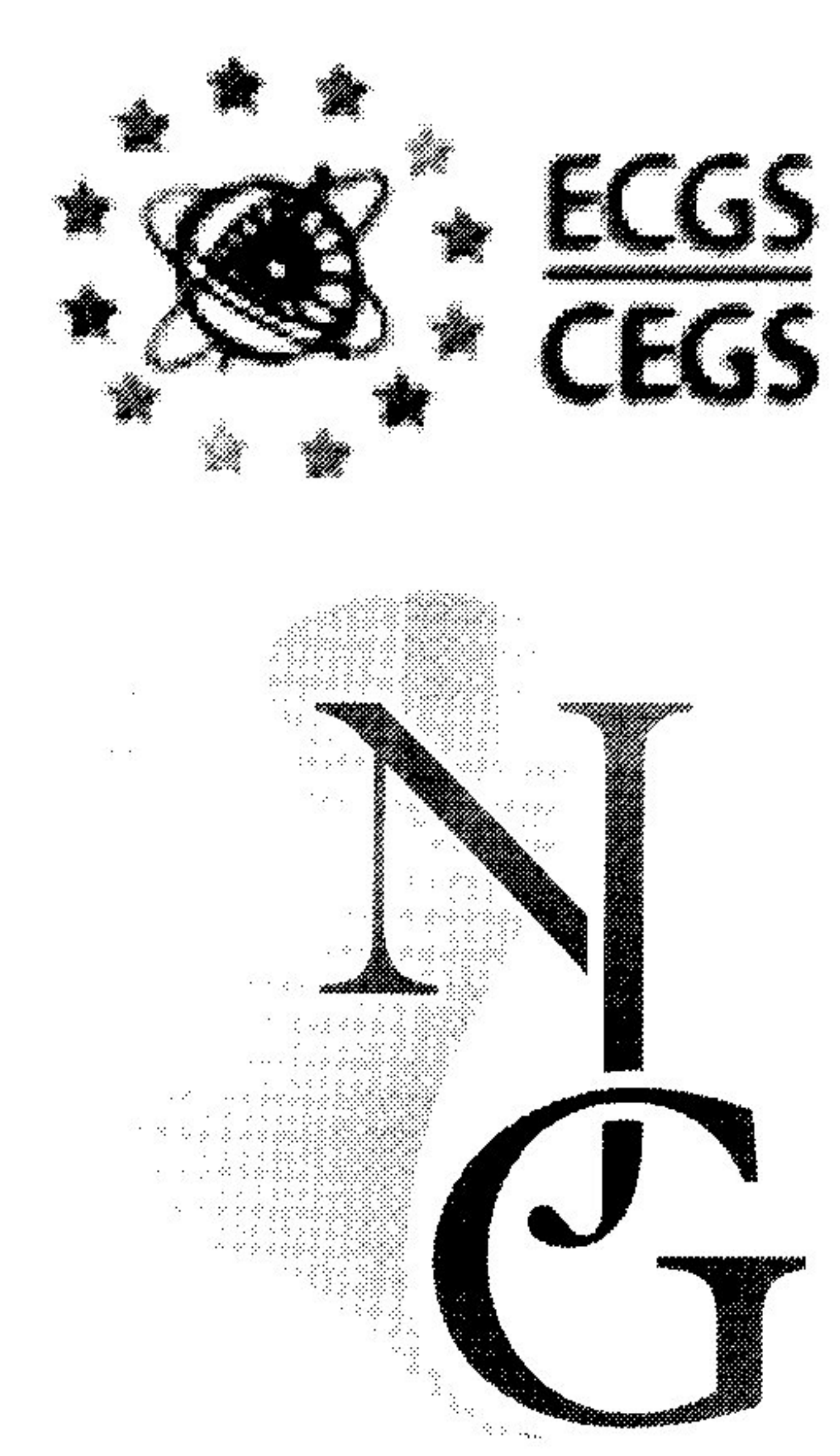

\begin{abstract}
We studied the applicability of classical scarp degradation modelling to active normal faults in the Lower Rhine Embayment. Our quantitative analysis was conducted on the frontal Bree fault scarp (Feldbiss fault) in Belgium and the Peel fault scarp near the city of Neer in the Netherlands. Vertical offset and diffusion age of these scarps have been modelled from elevation profiles across the studied faults using the diffusion equation. For that purpose, a computer-program (profil2000) has been written, providing a sensitivity analysis of the determined parameters in function of the spatial repartition of the elevation measurements along the considered profiles. The results of this morphometric analysis have been validated by a comparison with the geologic record of the tectonic activity observed in the trenches excavated at the sites where the measurements have been conducted.

We conclude that the modelling can only be applied to study tectonic activity since the Last Glacial Maximum $( \pm 14-19 \mathrm{kyr}$ BP) because the surface expression of older paleoearthquakes in unconsolidated Late Pleistocene sediments has been erased by the strong erosive phase that occurred at the end of this glacial period. Even for Holocene scarps, morphologic dating seems very difficult because man-made perturbations destroyed surface evidence of the very recent fault activity in many sites. Nevertheless, we estimate that an appropriate value for the mass diffusivity constant for $\sim 1$-m-high scarps in the investigated region is 0.002 to $0.010 \mathrm{~m}^{2} / \mathrm{yr}$. On the other hand, vertical offsets can be determined with a good precision. These amount to respectively $\sim 1 \mathrm{~m}$ and 1,3 $\mathrm{m}$ since the Last Glacial Maximum on the Feldbiss fault in Belgium and the Peel fault near Roermond in the Netherlands.
\end{abstract}

Keywords: Erosion, fault scarp modelling, geomorphology, Roer Graben.

\section{Introduction}

Since our first paleoseismic investigations (Camelbeeck and Meghraoui, 1996, 1998; Vanneste et al., 1999) along the Bree fault scarp (fig. 1) in 1996, extensive field evidence indicates that the Quaternary normal faults bordering the Roer Graben can produce large earthquakes with surface ruptures.

By the analysis of four trenches excavated across the Bree fault scarp, the surface-rupture history along this scarp is now relatively well-known (Meghraoui et al., 2000; Vanneste et al., 2001). Evidence for co-seis- mic rupturing rather than long-term a-seismic fault creep is provided by the identification of different intervals of episodic faulting and colluvial wedges resulting from fault scarp degradation. Additional indications for co-seismic fault motion are found in the appearance of soft-sediment deformations (including liquefaction features) and linear extensional fissures at most sites. Six faulting events have been identified since $\pm 150 \mathrm{ka} \mathrm{BP}$. Trench-to-trench correlation of the three most recent events (table 1) is quite good and demonstrates fault activity during the Holocene and the late Pleistocene. 


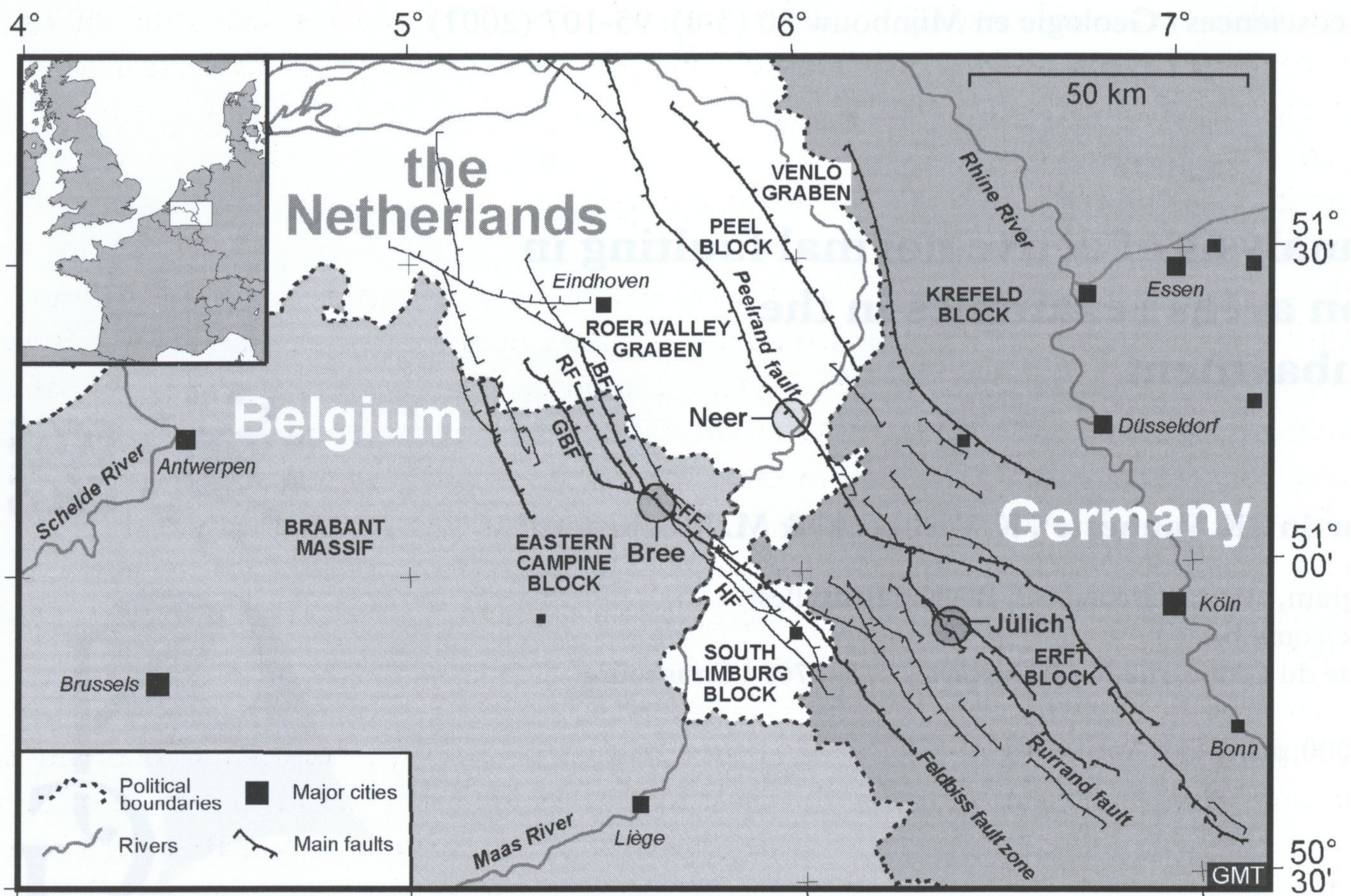

Fig. 1. Major Quaternary faults along the Lower Rhine Embayment. The Roer Graben is bounded on the northeast by the Peel fault and on the southwest by the Feldbiss fault zone (FF). North of the city of Bree, the Feldbiss fault divides into three faults : The Grote-Brogel fault (GBF), the Reppel fault (RF) and the Bocholt fault $(\mathrm{BF})$. Localities where paleoseismic investigations have been conducted during the PALEOSIS-project are indicated by the large circles (Bree, Neer and Jülich).

In the framework of the European project PALEOSIS, studies were initiated to investigate the seismogenic behaviour of other potentially active faults in the Lower Rhine Embayment (fig. 1), more specifically the Peel Boundary fault (van den Berg et al, 2001) near the village of Neer in the Netherlands, and the Rurrand fault (Lehman et al., 2001; Vanneste and Verbeeck, 2001) near the city of Jülich in Germany. Some of these preliminary studies seem to indicate that there is also evidence in favour of co-seismic slip and very recent activity along these faults. Paleoseismic investigations are time-consuming and expensive and it will not be possible to study all the possibly active fault fragments in the Lower Rhine Embayment by excavating a sufficient number of trenches. This is the reason why we examined the possibility to use only the morphological expression of Quaternary faults in this region to constrain their recent tectonic activity.

From topographic profiles across a fault scarp, it is possible to estimate the vertical offset and the quantity of material removed from the top of the scarp to its base by erosion since its creation. Numerous scientists studied this scarp degradation to obtain an esti- mate of their age (e.g. Bucknam and Anderson, 1979; Andrews and Hanks, 1985; Hanks and Andrews, 1989). Such a morphologic dating technique has been applied with relative success in arid or semi-arid areas but was never applied on fault scarps in western and central Europe where tectonic activity is far less important and climate humid and temperate.

The main purpose of our study is to determine how much the modelling of scarp degradation can be used in the Lower Rhine Embayment to date paleoearthquakes and to quantify the associated vertical offsets.

We used detailed topographic measurements conducted across the Bree fault scarp at four sites but also on one site across the Peel fault near the city of Neer in the Netherlands. The investigated sites have been chosen because there, the scarps have been identified without ambiguity as resulting from earthquake surface rupture from the geologic record observed in excavated trenches. The elevation profiles across the scarps have been analysed with a computer-program (profil2000) in which we consider scarp degradation as a classical diffusion process. The reliability of the estimated vertical offset and the diffusion

Table 1. Minimal vertical displacements and dating of paleoearthquakes suggested by the analysis of the four trenches excavated across the Bree fault scarp (Camelbeeck and Meghraoui, 1998. Meghraoui et al., 2000 and Vanneste et al., 2001).

\begin{tabular}{llllc}
\hline Earthquake & trench 1 & trench 2 & trench 3 & trench 4 \\
\hline Most recent $(600-900 \mathrm{AD})$ & $0.5 \mathrm{~m}$ & $0.7 \mathrm{~m}$ & $0.7 \mathrm{~m}$ & $0.12 \mathrm{~m}$ \\
Penultimate $(15.8 \mathrm{ka}-14 \mathrm{ka} \mathrm{BP})$ & event with unknown & $0.7 \mathrm{~m}$ & $0.33 \mathrm{~m}$ & amount of slip \\
Antepenultimate $(30.5 \mathrm{ka}-22.6 \mathrm{ka} \mathrm{BP})$ & event with unknown & $1.2 \mathrm{~m}$ & $1.0 \mathrm{~m}$ & amount of slip \\
\hline
\end{tabular}


age is generally not enough taken into consideration in this kind of analysis. We consider it as fundamental in the applicability of the method. Two different aspects have been developed. Firstly, The profil 2000 software provides a sensitivity analysis of the determined parameters in function of the spatial repartition of the elevation measurements along the considered profiles. Secondly, using the different profiles measured on the same sites and corresponding to the same deformed geomorphic surface, the possible range of values for the vertical offset and the diffusion age have been obtained. Finally, the applicability of the methodology to active fault scarps in the Lower Rhine Embayment is discussed in the light of the comparison between the calculated values and their uncertainties from elevation measurements and the vertical offsets and dating of past large earthquakes as observed in the trenches excavated at the same sites.

\section{Recent fault activity in the morphology}

Quaternary fault activity in the Lower Rhine Embayment is expressed in the morphology by gentle es- carpments resulting from the vertical offset of the Middle Pleistocene deposits of the Maas and Rhine rivers.

\section{Bree fault scarp}

A typical example is the prominent northwest southeast trending fault scarp near the town of Bree (Belgian Limburg, fig. 1) which separates the Campine Plateau to the west from the Roer Graben to the east. It defines a 10-km-long scarp with $15-20$ $\mathrm{m}$ of topographic offset (fig. 2). It results from the complex interaction between tectonic deformation, erosion, slope processes and also deposition of aeolian cover-sands during several glacial periods.

It is known since 1908 (Briquet, 1908) as the geomorphic expression of the Feldbiss fault. The entire Feldbiss fault zone displaces the main terrace of the Maas river (formed between 700 and $350 \mathrm{ka} \mathrm{BP}$ ) by a vertical amount of $\pm 40 \mathrm{~m}$ (Beerten et al., 1999). Superposed on this gentle but noticeable morphology, detailed field work and geodetic levelling revealed the existence of a frontal fault scarp. In each of the four

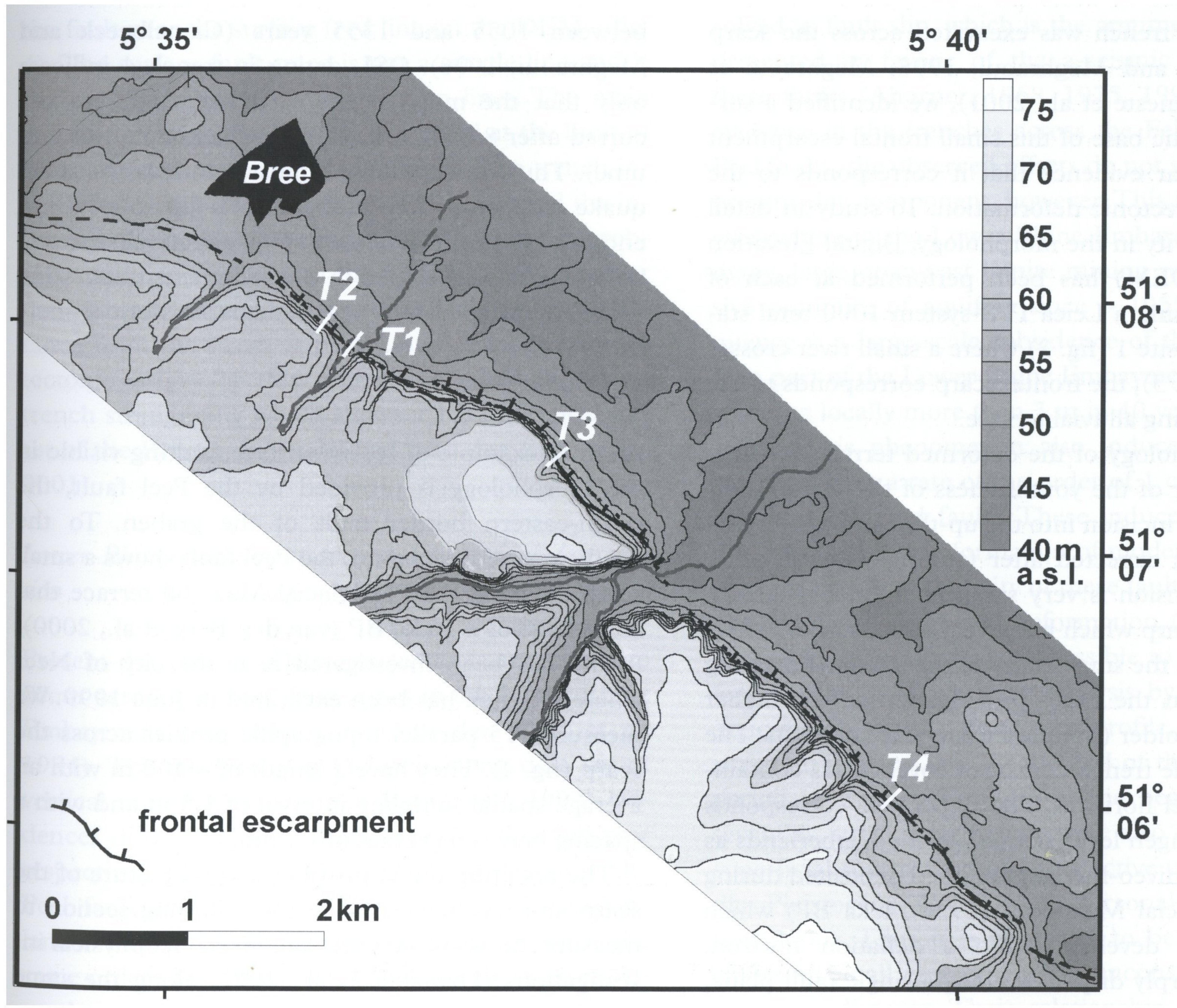

Fig. 2. Morphotectonic map showing the main section of the Bree fault scarp and the sites where four trenches were excavated (T1 and T2 in $1996, \mathrm{~T} 3$ in 1997, T4 in 1998 and T1bis in 1999) to investigate the earthquake history of the fault. 


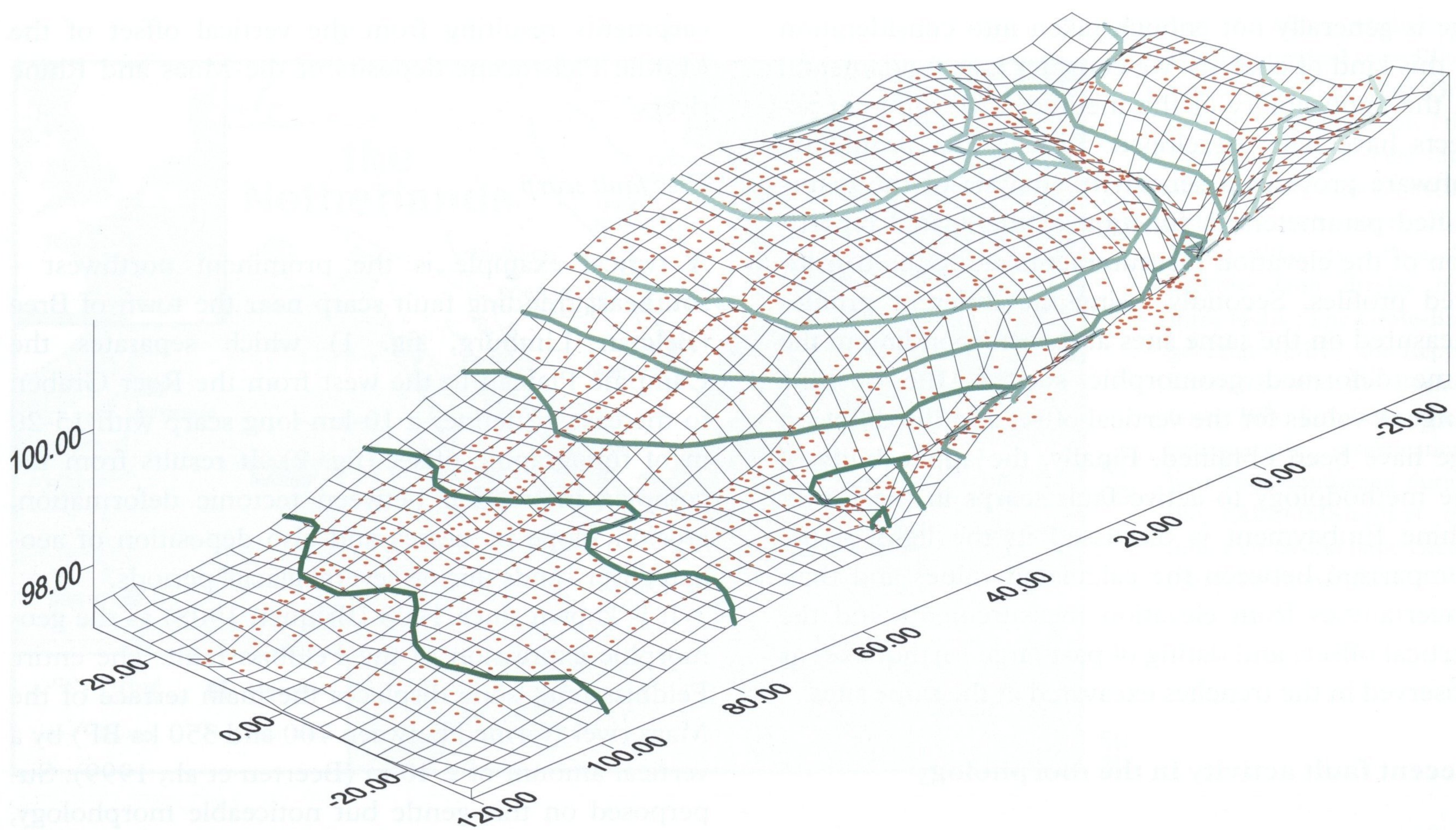

Fig. 3. Digital Elevation Model at site 1. Red points correspond to the measured points. Contour interval is $0.5 \mathrm{~m}$. One can note the stream incision into the up-thrown block.

sites where a trench was excavated across the scarp (Camelbeeck and Meghraoui, 1998; Meghraoui et al., 2000; Vanneste et al., 2001), we identified a surface fault at the base of this small frontal escarpment providing clear evidence that it corresponds to the most recent tectonic deformation. To study in detail the fault activity in the morphology, Digital Elevation Modelling (DEM) has been performed at each of these sites, using a Leica TPS-system 1000 total station. At Bree site 1 (fig. 2) where a small river crosses the scarp (fig. 3), the frontal scarp corresponds to the offset of a young alluvial terrace.

The morphology of the deformed terrace is a reliable indicator of the youthfulness of the tectonic activity. Stream incision into the up-thrown block is well visible and is expected after faulting. On the other hand, the incision is very small in the down-thrown block. The scarp which has a very small vertical offset $(\sim 1 \mathrm{~m})$ inside the small valley of the stream, on young deposits, is in the exact prolongation of the higher scarp on the older (middle Pleistocene) deposits. The deposits in the trench consist of cover-sands containing two gravel horizons. The upper one corresponds to the Beuningen level, defined in the Netherlands as a prominent niveo-fluvial gravel bed deposited during the Last Glacial Maximum (19 - 14 ka BP) which subsequently developed into a deflation horizon. They are sharply displaced along a single fault plane, with a total offset of $\pm 1 \mathrm{~m}$ similar to that in the morphology. Initial radiocarbon dating suggested an age between 1055 and 1355 years (Camelbeeck and Meghraoui, 1996). OSL dating in trench 4 indicate only that the most recent earthquake rupture occurred after $8.5 \pm 1.5 \mathrm{ka} \mathrm{BP}$ (Frechen et al., this volume). Thus, the age of the most recent large earthquake along the Bree fault scarp is up to now not enough constrained. However, it affects all the soil horizons that developed in the sediments, suggesting a late Holocene occurrence, perhaps a historical one.

\section{Peel fault at Neer}

Another example of recent surface faulting visible in the morphology is provided by the Peel fault, the north-eastern border fault of the graben. To the north-west of Roermond, the Peel fault shows a small scarp affecting the Pleniglacial Maas fill terrace that has an age of $\pm 16 \mathrm{ka} \mathrm{BP}$ (van den Berg et al., 2000). A site has been investigated near the city of Neer where a trench has been excavated in June 1999. We measured 15 parallel topographic profiles across the scarp (fig. 4). They have a length of $\sim 100 \mathrm{~m}$ with an average spatial sampling interval of $1.5 \mathrm{~m}$ and with a spacing between profiles of $\sim 10 \mathrm{~m}$.

The resulting DEM provides a good picture of the scarp and has been used in the following section to measure the associated vertical offset. Geophysical investigations (Demanet et al., 2001) along the same profiles ( Ground Penetrating $\underline{R}$ adar, electric tomography and high-resolution seismic reflection) identify 

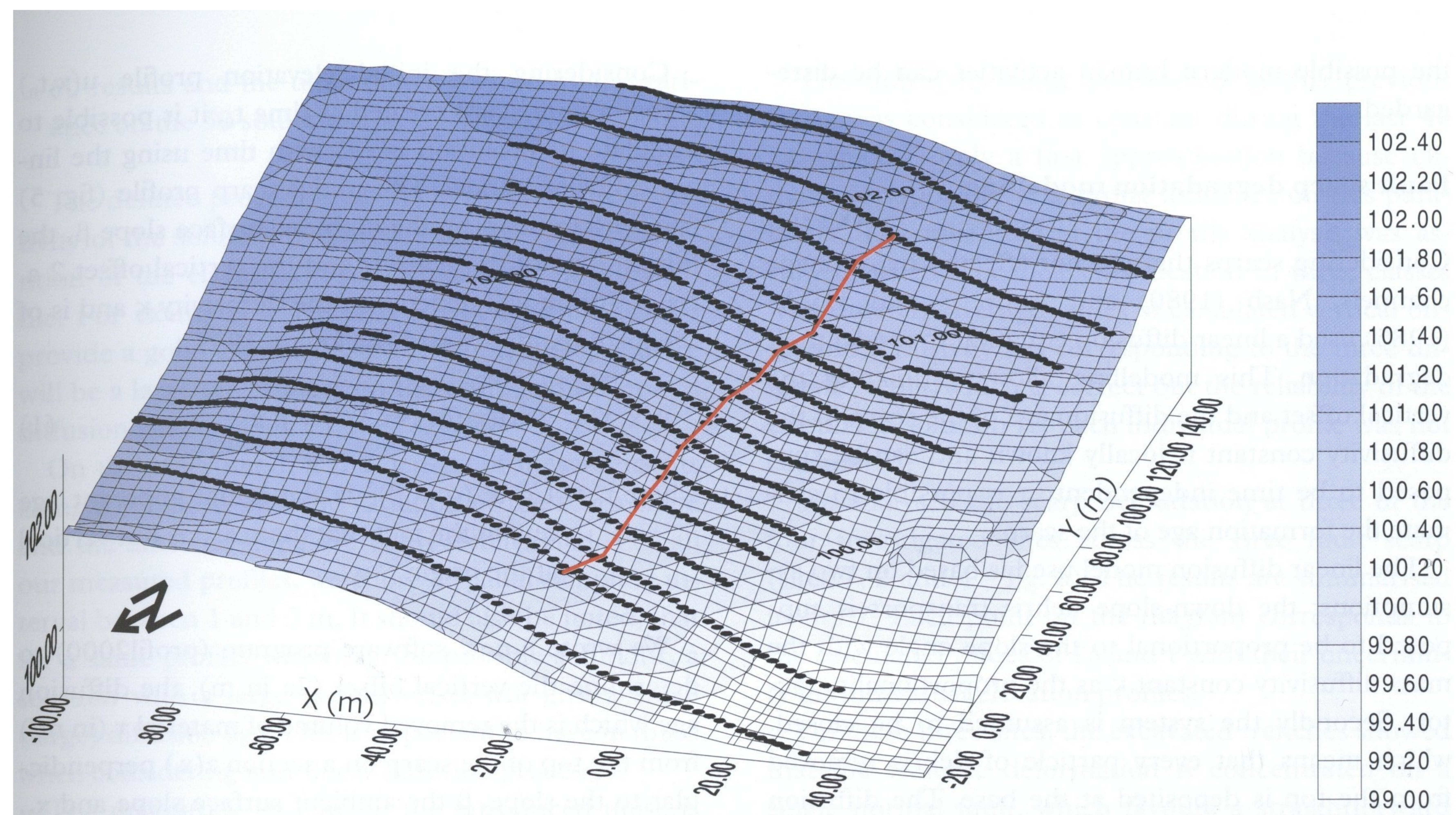

Fig. 4. DEM at the site near Neer (The Netherlands) where a trench has been excavated in 1999 across the Peel Boundary fault. The red line corresponds to the position of the fault at the surface as determined by geophysical investigations (Demanet et al., this volume) and the black dots are the measured points.

the fault near the surface (red line on the DEM - fig. 4). The surface fault trace is not a simple line and is not exactly parallel to the elevation lines. The main reason for this is that the site is located at the limit of a stream incision in the Maas terrace. The trench investigation (van den Berg et al., 2001) showed the influence of extensive farming activity, which has probably modified the slope of the scarp as well ; however the ambient slope is preserved at least at some distance from the scarp. A post Last Glacial Maximum tectonic origin of this scarp is confirmed by the trench stratigraphy which shows a $1.3 \mathrm{~m}$ vertical offset of the Beuningen gravel bed (van den Berg et al., 2001).

Lower Rhine embayment present-day vertical deformation

Present-day vertical relative movements are known to occur across the main fault zones in the Lower Rhine Embayment (Ahorner, 1968; van den Berg et al, 1994). The analysis of a 117-years-long data set of vertical movements (van den Berg et al., 1994) evidences differential movement of 0.5 to $0.8 \mathrm{~mm} /$ year respectively between the blocks on either side of the Peel fault and of the Feldbiss fault in the Netherlands. The uncertainties on these values have the same order of magnitude as the values themselves. Also, the spatial resolution of the measurements was not sufficient to determine if these movements are re- solved as fault slip, which is the argument commonly presented in favour of the a-seismic behaviour of these faults (Ahorner, 1968, 1975, 1997). From the evidence in the trenches across the Feldbiss and the Peel faults, the observed offsets do not seem to have a present-day component, however. This is not the case everywhere in the Lower Rhine Embayment. In Germany, large open-cast lignite mining required extensive pumping of aquifers since $\sim 1955$. The consequence is a large-scale subsidence of the entire German part of the Lower Rhine Embayment with values reaching locally more than $3 \mathrm{~m}$ in 40 years (Schaefer, 1999). This phenomenon also induced continuous vertical slip at a rate of the order of $1 \mathrm{~cm} /$ year on the Erft and Rurrand faults. These induced movements have resulted in the formation of modern scarps. The study of the recent activity of these faults is thus complicated by this induced deformation (Vanneste and Verbeeck, 2001). It may be possible to eliminate this factor from the fault scarp analysis by detailed geodetic measurements along each profile. This example is not an isolated one. At the end of the coal mining period in Belgian Limburg at the beginning of the seventies, small escarpments were also created by the superficial reactivation of faults active up to the Middle Pleistocene (M. Dusar, personal communication 2000). Thus it is necessary to be careful when analysing small escarpments in unconsolidated Quaternary sediments. Their relationship with tectonic activity can only be accepted after the influence of all 
the possible modern human activities can be disregarded.

\section{Fault scarp degradation modelling}

Considering scarps that are not affected by drainage channels, Nash (1980) and Andrews and Hanks (1985) used a linear diffusion equation to model their degradation. This modelling allows estimating the vertical offset and the diffusion age of the scarp. If the diffusivity constant is locally known and can be supposed to be time independent, it is possible to estimate the formation age of the scarp.

The linear diffusion model used is based on two assumptions: the down-slope debris transport is supposed to be proportional to the slope angle with the mass diffusivity constant $\kappa$ as the proportionality factor. Secondly the system is assumed to be closed, which means that every particle of debris removed from the top is deposited at the base. The diffusion equation can be obtained in the following way (Andrews and Hanks, 1985):

- Elevation along a profile depends on only one space coordinate and time: $\mathrm{u}=\mathrm{u}(\mathrm{x}, \mathrm{t})$

- flux of mass downslope depends on the local slope: $\mathrm{S}=-\mathrm{K} \partial \mathrm{u} / \partial \mathrm{x} ;$ where

- $\mathrm{S}$ is the mass transported in the cross-strike direction per unit time per unit length along strike

- $\mathrm{K}$ is the transport coefficient

- Mass conservation: $\partial \mathrm{u} / \partial \mathrm{t}=-(1 / \rho) \partial \mathrm{S} / \partial \mathrm{x}$ ( $\rho$ is the density)

$\partial \mathrm{u} / \partial \mathrm{t}=\partial(\kappa \partial \mathrm{u} / \partial \mathrm{x}) / \partial \mathrm{x}$

where

$\kappa=\mathrm{K} / \rho$ is the diffusivity [lenght ${ }^{2 /}$ [time]

$\tau=\kappa \mathrm{t}$ is the diffusion time scale, equal to the diffusion age when it is measured from the origin time of the scarp
Considering the initial elevation profile $\mathrm{u}\left(\mathrm{x}, \mathrm{t}_{0}\right)$ across a fault scarp created at time $t_{0}$, it is possible to calculate its evolution $\mathrm{u}(\mathrm{x}, \mathrm{t})$ with time using the linear diffusion model. The initial scarp profile (fig. 5) can be described by the ambient surface slope $\beta$, the initial slope of the scarp $\alpha$ and the vertical offset 2 a. Its evolution will depend on the diffusivity $\kappa$ and is of the form (Andrews and Bucknam, 1987):

$$
\mathrm{u}(\mathrm{x}, \tau)=\mathrm{a} \operatorname{erf}\left(\mathrm{x} /\left(4\left(\tau+\tau_{0}\right)^{1 / 2}\right)+\beta \mathrm{x}\right.
$$

where $\tau_{0}=1 / 6 \mathrm{a}^{2} /(\alpha-\beta)^{2}$ is the initial apparent age due to the fact that the scarp is not vertical at the origin.

We wrote a new software program (profil2000) to determine the vertical offset ( $2 \mathrm{a}$ in $\mathrm{m}$ ), the diffusion age which is the removed volume of material $\tau$ (in $\mathrm{m}^{2}$ ) from the top of the scarp on a section $\mathrm{z}\left(\mathrm{x}_{\mathrm{i}}\right)$ perpendicular to the slope, $\beta$ the ambient surface slope and $x_{M}$ the $\mathrm{x}$-value along the profile corresponding to half of the vertical offset.

The program samples the space parameters $(2 \mathrm{a}, \tau$, $\left.\beta, x_{M}\right)$ between realistic boundaries to determine the optimal value of the parameters giving the elevation $\mathrm{u}\left(\mathrm{x}_{\mathrm{i}}, \tau\right)$ calculated with formula (1) as close as possible to the measured $z\left(x_{i}\right)$ for the different values of $i$. The program allows to use the least-squares sum L2 $=\Sigma_{\mathrm{i}}\left(\mathrm{z}\left(\mathrm{x}_{\mathrm{i}}\right)-\mathrm{u}\left(\mathrm{x}_{\mathrm{i}}, \tau\right)\right)^{2}$ or the absolute difference sum $\mathrm{L} 1=\Sigma_{\mathrm{i}}\left|\left(\mathrm{z}\left(\mathrm{x}_{\mathrm{i}}\right)-\mathrm{u}\left(\mathrm{x}_{\mathrm{i}}, \tau\right)\right)\right|$. The adopted solution will be that minimising L2 or L1.

To obtain a realistic estimation of the uncertainties in the determined parameters for each measured profile $z(x)$, we introduced the following procedure:

- a stochastic noise corresponding to a $\sigma$ of $0.1 \mathrm{~m}$ is added to each value of elevation $\mathrm{z}(\mathrm{x})$.

- we define by this way 50 different profiles $\mathrm{z}(\mathrm{x})$.

- each of the 50 profiles is inverted by the program.

- the adopted parameters are the average value of the

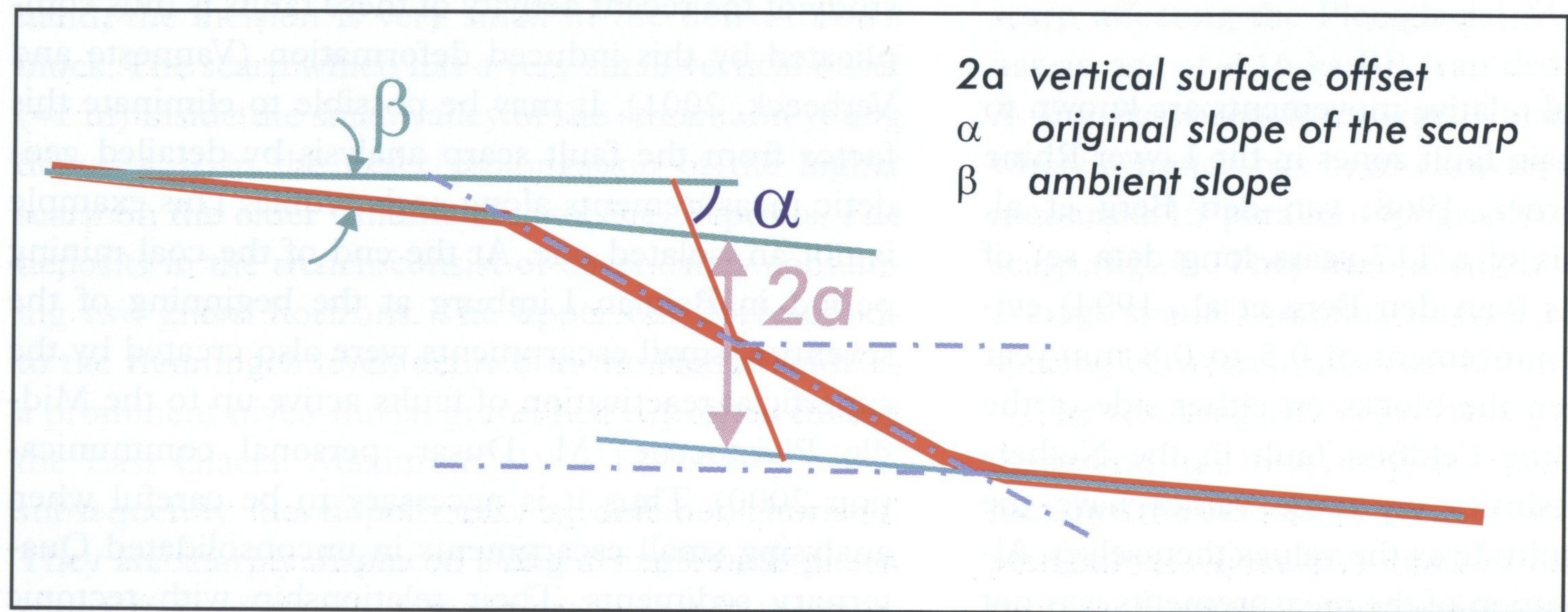

Fig. 5. Geometrical parameters used to define a fault scarp (modified from Andrews and Hanks, 1985). 
50 results and the uncertainty is given by the variance on the 50 solutions.

The defined procedure allows to measure the sensitivity of the solution parameters for the spatial repartition of the elevation measurements along our profile. For example, if a profile is not long enough to provide a good estimation of the ambient slope, there will be a large uncertainty on the estimated offset and diffusion age.

On the other hand, if the density of measurements along a profile is low, the variation of the scarp slope and the ambient slope are badly determined. For all our measured profiles, we chose a spatial sampling interval between 1 and $2 \mathrm{~m}$. It should also be noted, that for a same profile, within all the possible solutions, a solution with a large (small) offset will give a small (large) diffusion age. This is important to have in mind when considering non-linear diffusion processes.

The magnitude $(0.1 \mathrm{~m})$ of the introduced noise is larger than the precision of the measurement $(0.01$ $\mathrm{m})$, but it allows to take partially into account the local variability of the elevation along the profile which can be due to natural causes or to human activities (e.g. ploughing).

The advantage of the developed procedure is that it is not necessary to beforehand select the profiles to study, as it is usually done, in order that the analysis be meaningful. The results of the analysis of the different profiles will indicate for each of them in function of the parameter uncertainties if they are good or not for the study.

\section{Geomorphic analysis of the Bree and Peel fault scarps and comparison with the trench analysis}

In a previous paper (Meghraoui et al., 2000), we studied geomorphic profiles conducted across the Bree fault scarp by using the computer programs of Nash (1980) and Andrews and Hanks (1985). We observed three different groups of vertical displacements from the 36 conducted profiles. The group with the largest diffusivity age is likely related with cumulative fault movements rather than to an individual earthquake as is assumed for the two other groups. We estimated their age in the hypothesis that the erosion conditions have remained stable since the occurrence of the antepenultimate event. A diffusivity value in the range of $0.01-0.08 \mathrm{~m}^{2} / \mathrm{yr}$ was used. Considering all these hypotheses, morphologic dating gives approximate ages of $2 \pm 1.5 \mathrm{ka} \mathrm{BP}, 14 \pm 5 \mathrm{ka} \mathrm{BP}$ and 41 $\pm 6 \mathrm{ka} \mathrm{BP}$ for the three most recent large earthquakes, which are in good agreement with faulting events dated in trenches.
The diffusivity value considered in this previous study was considered as constant during the last 40 $\mathrm{ka}$, which is only a first approximation because climatic variations have a strong influence on this parameter. The reliability of the profile analysis was assumed because of their classification in three classes with different average values of calculated vertical offset and diffusivity age corresponding to the three different events, which is correct but the reliability of the calculated solution for each individual profile was not considered.

We analysed the scarp degradation at three of the four investigated sites across the Bree fault scarp (sites 1,2 and $4-$ fig. 6). The results are summarised in fig. 7. Each point on the diagram corresponds to the calculated values of $2 \mathrm{a}$ and $\tau$ with their uncertainty for individual elevation profiles.

On these three sites, the excavated trenches showed that the tectonic deformation is concentrated on a single normal fault, which favours a straightforward relationship between geomorphology and tectonic deformation. Site 3 is not considered in our analysis because it is located on the eastern flank of a stream incision perpendicular to the scarp, making the erosion modelling too complicated. In addition, the excavated trench showed a more complex fault zone where the recent deformation is divided over three different faults that are distributed over a 30-m-wide zone.

For site 2, all the solutions are contained in the same region of the diagram $(2 \mathrm{a}, \tau)$ and range from 0.90 to $1.33 \mathrm{~m}$ for the vertical offset and from 7.2 to $18.5 \mathrm{~m}^{2}$ for the diffusion age. For sites 1 and 4 , half of the profiles are concentrated around relatively low values of $\tau$ smaller than $30 \mathrm{~m}^{2}$, whereas the results for the other profiles are more dispersed. For most of these latter profiles, the uncertainties are large for the two considered parameters. The main reason is that these profiles are not long enough to allow a reliable determination of the ambient slope.

On site 1 (fig. 3), the cause is the meandering of the small river in the foot-wall relatively close to the scarp. On site 4 , the profiles are interrupted by a grove in the foot-wall but there is also a local accumulation of cover-sands just below the surface in the hanging-wall, which is responsible for a difference of the slope on the two sides of the scarp. For the former profiles, the calculated offsets are reliable $( \pm 5$ to $20 \%)$. The scatter on $\tau$ is generally high, even in the best cases ( \pm 20 to $50 \%$ ).

The weighted average values for $2 \mathrm{a}$ and $\tau$ for each site are indicated in table 2 . The calculated vertical topographic offsets can be compared with the offsets observed inside the trenches (table 1 ). In trench 2 , the 

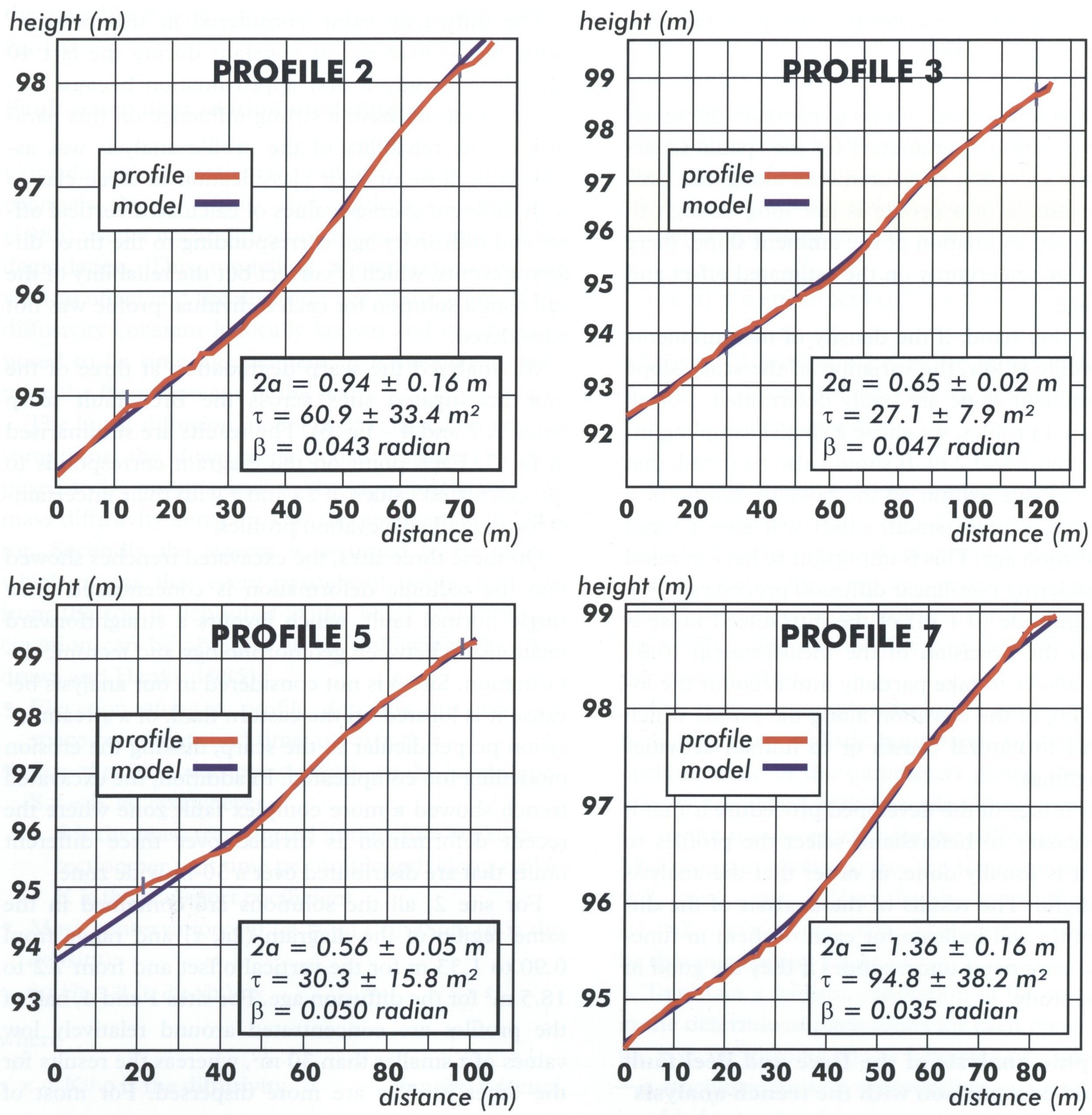

height (m)
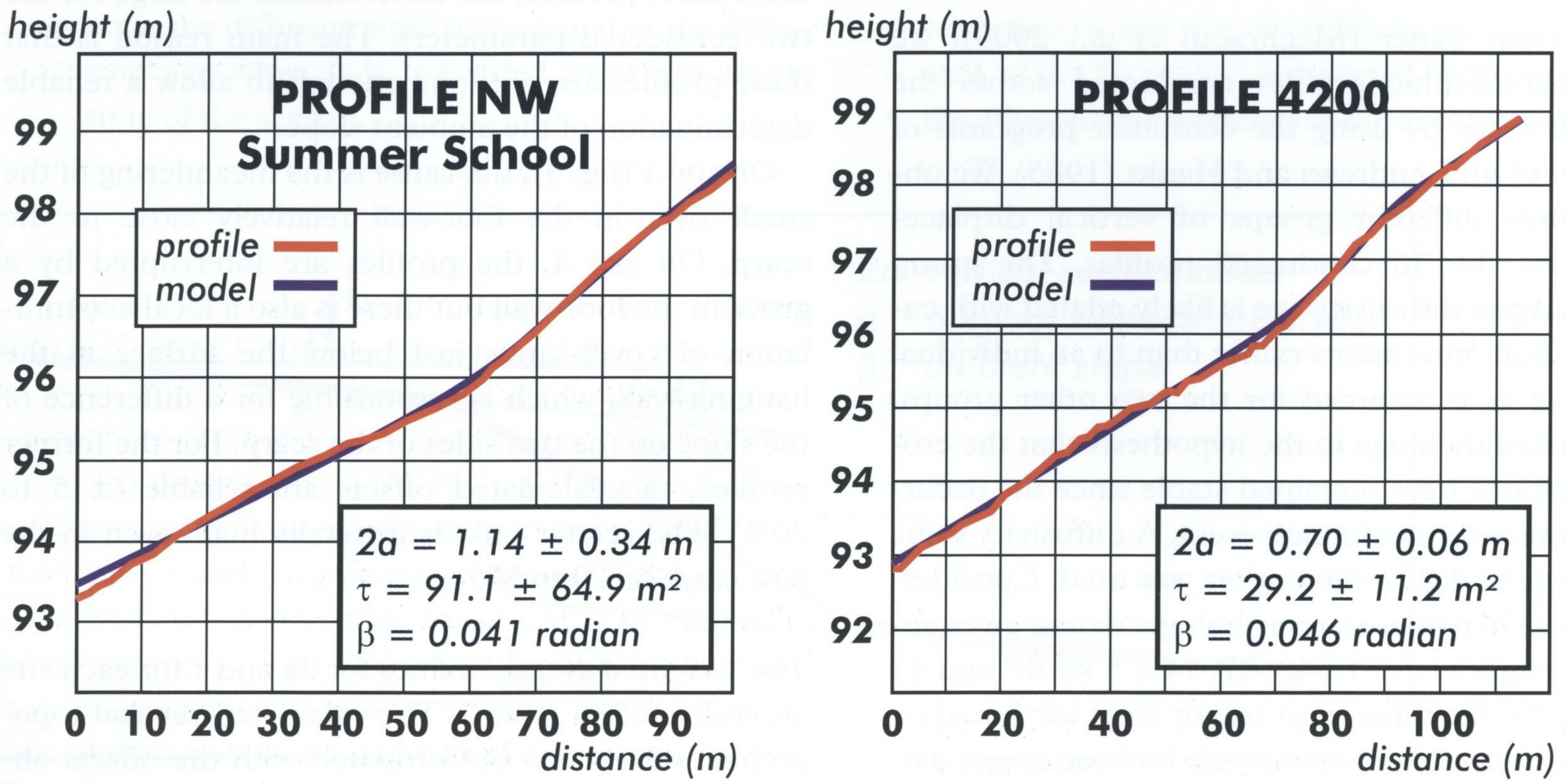

Fig. 6. Scarp degradation analysis of the topographic profiles across the Bree fault scarp at site 4 . 


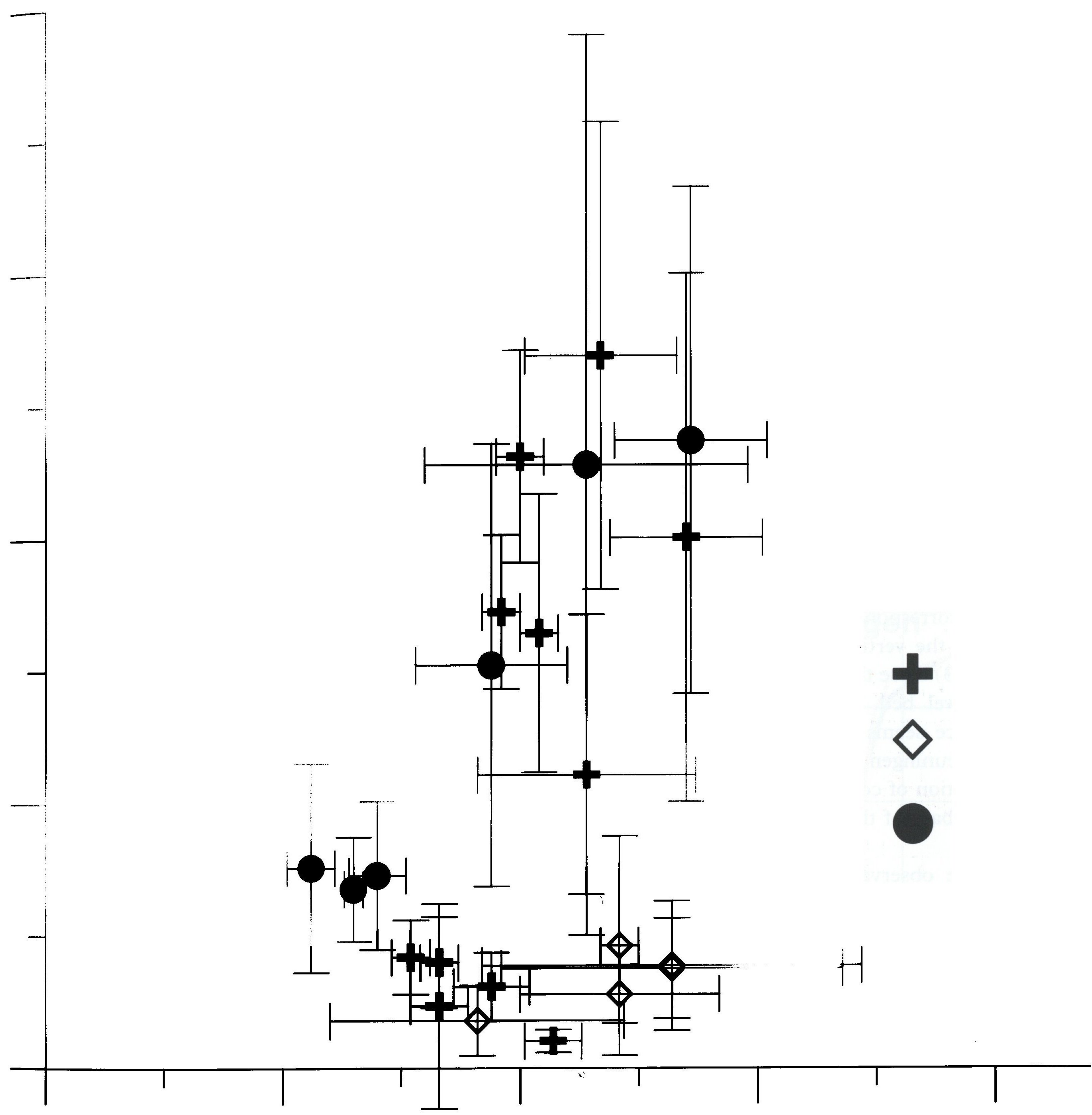

Fig. 7. Relationship between vertical offset and diffusivity age for sites 1,2 and 4 along the Bree fault scarp. The indicated error bars are the 1 $\sigma$ uncertainty on the inverted values.

vertical displacement of $0.7 \mathrm{~m}$ due to the most recent large earthquake is very uncertain because it was estimated using the colluvial wedge dimension. This is less than the $1.16 \pm 0.15 \mathrm{~m}$ estimated from the mor-

Table 2. Weighted average values of $2 \mathrm{a}$ and $\tau$ for the analysed profiles at sites 1,2 and 4 along the Bree fault scarp.

\begin{tabular}{llll}
\hline & Site 1 & Site 2 & Site 4 \\
\hline $2 \mathrm{a}$ & $0.94 \pm 0.03 \mathrm{~m}$ & $1.16 \pm 0.15 \mathrm{~m}$ & $0.71 \pm 0.04 \mathrm{~m}$ \\
$\tau$ & $22.2 \pm 16.8 \mathrm{~m}^{2}$ & $11.4 \pm 5.9 \mathrm{~m}^{2}$ & $39.4 \pm 21.2 \mathrm{~m}^{2}$ \\
\hline
\end{tabular}

phology. Inside trenches 1 and 4, we were able to measure an elevation profile of faulted gravel horizons and to determine their vertical offset (fig. 9, table 3) caused by the most recent surface faulting event using the same approach as for the surface morphology.

In both trenches, this gravel layer corresponds to the already mentioned Beuningen desert pavement. The studied gravel layers in trenches 1 and 4 are respectively displaced at the fault by an amount of 0.50 $\mathrm{m}$ and $0.12 \mathrm{~m}$, but the total offset is higher, respectively $1.0 \mathrm{~m}$ and $0.78 \mathrm{~m}$ when considering the flexure around the fault zone. These total offsets correspond 
Table 3. Recent estimated vertical offsets in Bree trenches 1 and 4 (Feldbiss fault) and the Neer trench (Peel fault).

\begin{tabular}{|c|c|c|c|c|}
\hline & \multicolumn{3}{|l|}{ Feldbiss fault } & \multirow{2}{*}{$\frac{\text { Peel fault }}{(\mathrm{m})}$} \\
\hline & $\mathrm{T} 1(\mathrm{~m})$ & $\mathrm{T} 2(\mathrm{~m})$ & $\mathrm{T} 4(\mathrm{~m})$ & \\
\hline Surface topo & $0.94 \pm 0.03$ & $1.16 \pm 0.15$ & $0.71 \pm 0.04$ & $1.11 \pm 0.18$ \\
\hline Gravel $(\mathrm{F}+$ flex $)$ & $0.90 \pm 0.02$ & & $0.78 \pm 0.13$ & $1.28 \pm 0.11$ \\
\hline Gravel F & 0.50 & & 0.12 & 0.85 \\
\hline
\end{tabular}

Gravel $(F+f l e x):$ gravel layer ( = Beuningen in Bree trench 4 and Neer) total vertical offset

Gravel F: gravel layer (= Beuningen in Bree trench 4 and Neer) vertical offset as slip on faults

to the offsets measured at the ground surface. Several indications have been found (Camelbeeck and Meghraoui, 1996, 1998; Vanneste et al., 1999 Meghraoui et al., 2000; Vanneste et al., 2001) for a co-seismic origin of the slip at the fault, but it is impossible to determine if the flexure is co-seismic or not.

We conducted similar measurements across the Peel fault at the Neer site (fig. 4) where a trench has been excavated in 1999. The vertical offset in the morphology corresponds within the range of the uncertainties to the vertical offset observed inside the trench (table 3) since the formation of the Beuningen erosional gravel bed. The estimated offset for the ground surface seems nevertheless $0.2 \mathrm{~m}$ less than that of the Beuningen level. This could be explained by the deposition of coversands (van den Berg et al., 2001) at the base of the scarp after the surface rupture.

From these observations, the importance of the strong erosion phase during the Last Glacial Maximal is evidenced. This phase has been identified in the four trenches excavated across the Bree fault scarp and in the Neer trench across the Peel fault. Thus, the visibility of a fault escarpment in an area covered by soft sediments deposited during the Weichselian (mainly cover-sands in the studied area) implies that this scarp results from tectonic activity since the Last Glacial Maximum (19 - 14 ka B.P.). The best example is at the Neer site.

The considered gravel horizons inside the different trenches have not been affected by the scarp degradation. Thus, the original dip of the surface fault as it is shown by the gravel displacement, has been preserved. The diffusivity age calculated for these horizons gives an estimation of the apparent age of the scarp before it reaches its equilibrium corresponding to a slope equal to the repose angle of the sediments. In Bree trench 1, the method gives $\tau=0.2 \mathrm{~m}^{2}$ for the measured gravel layer whereas it is $\tau=0.6 \mathrm{~m}^{2}$ for the Beuningen gravel bed in the Neer trench. These values are comparable to the $\sim 0.5 \mathrm{~m}^{2}$ initial apparent age of a 1-m-high scarp with ambient slopes similar to the studied one's and with a repose angle of $35^{\circ}(\alpha$ $=0.61$ ).

In Bree trench 4, we found $\tau=32 \pm 16 \mathrm{~m}^{2}$ for the Beuningen layer (fig. 8).

As the Beuningen gravel bed is a deflation horizon, an explanation of this high value relative to that obtained in Bree trench 1 or in Neer is that a pre-existent scarp may not have been completely levelled by the strong erosion phase associated with the Last Glacial Maximum. The reason could be the difference in resistance to erosion of the sediments on the two sides of the fault zone (coarse-grained main Maas river terrace in the foot-wall versus finer-grained cover-sands in the hanging-wall). Thus a part of the 78 $\mathrm{cm}$ vertical offset could predate the time of the Beuningen layer formation. Another possible explanation is that a-seismic deformation produced a flexure of the different geologic horizons since the Beuningen formation. This example testifies the complexity of the interpretation when the sediments have different mechanical behaviour on the two sides of the fault, and the impossibility in western Europe to use geomorphic measurements to infer vertical offset and age for scarps older then $14 \mathrm{ka}$.

By the comparison of the vertical offset measured in the trenches and in the morphology, we can conclude that the diffusion age calculated for sites 1 and 2 (table 2) corresponds to the age of the most recent surface rupture. That of trench 4 must be diminished by the apparent age obtained for the Beuningen level, giving a value of $7.4 \mathrm{~m}^{2}$ (with a large uncertainty). Thus, the weighted diffusion age average value for this event is $13 \pm 4 \mathrm{~m}^{2}$. Along the Bree fault scarp, the average vertical offset at the three studied sites is $\sim 1$ $\mathrm{m}$.

Considering the different hypotheses on the age of this event and its uncertainty, the mass diffusivity constant since the Last Glacial Maximum can be estimated between 0.002 to $0.010 \mathrm{~m}^{2} / \mathrm{yr}$. The assumption that the system has to be closed for using the diffusion model is not valid for the time span between the formation of the Beuningen gravel bed and the beginning of the Holocene; due to the deposition of Older 
height (m)
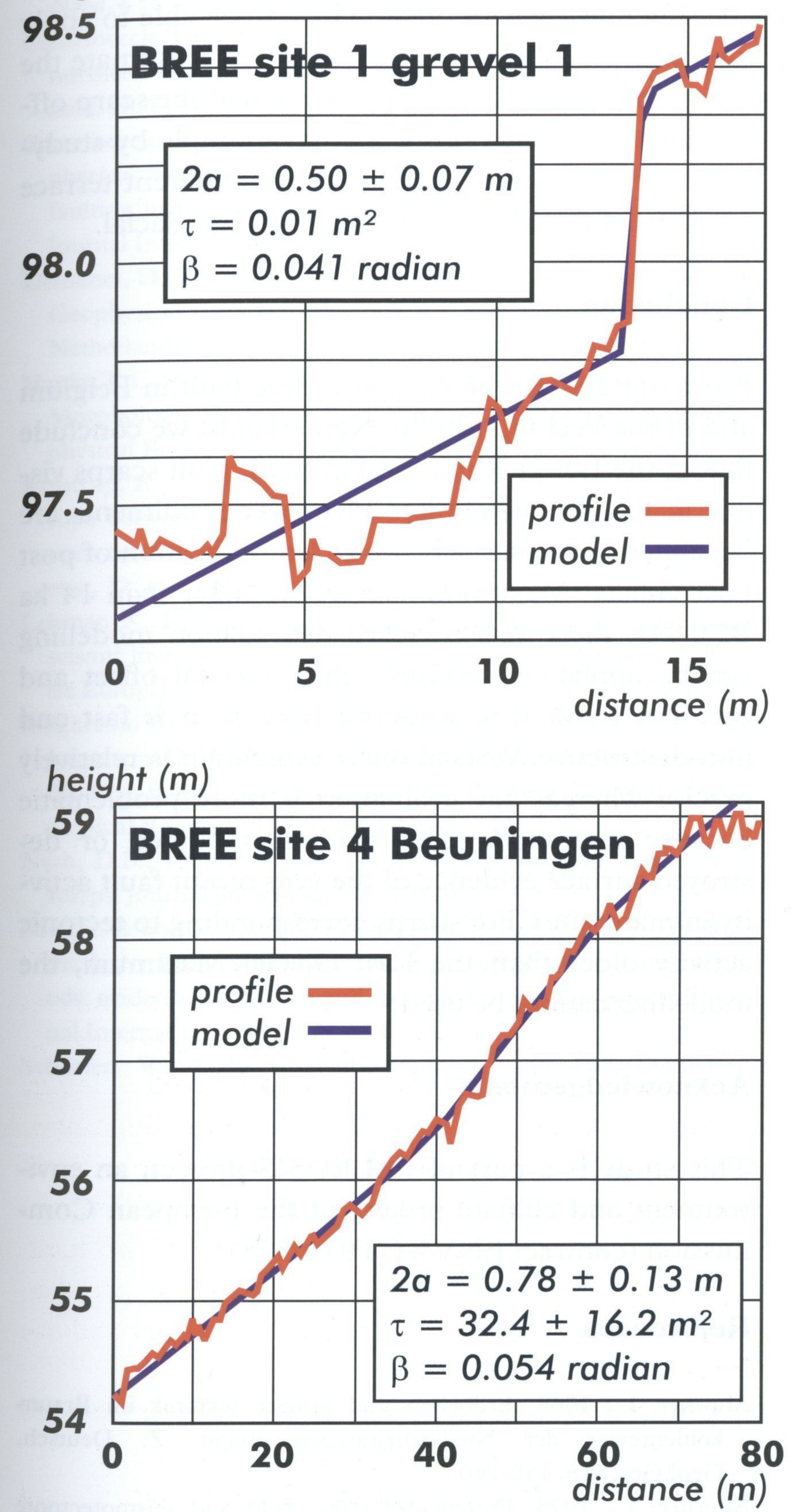
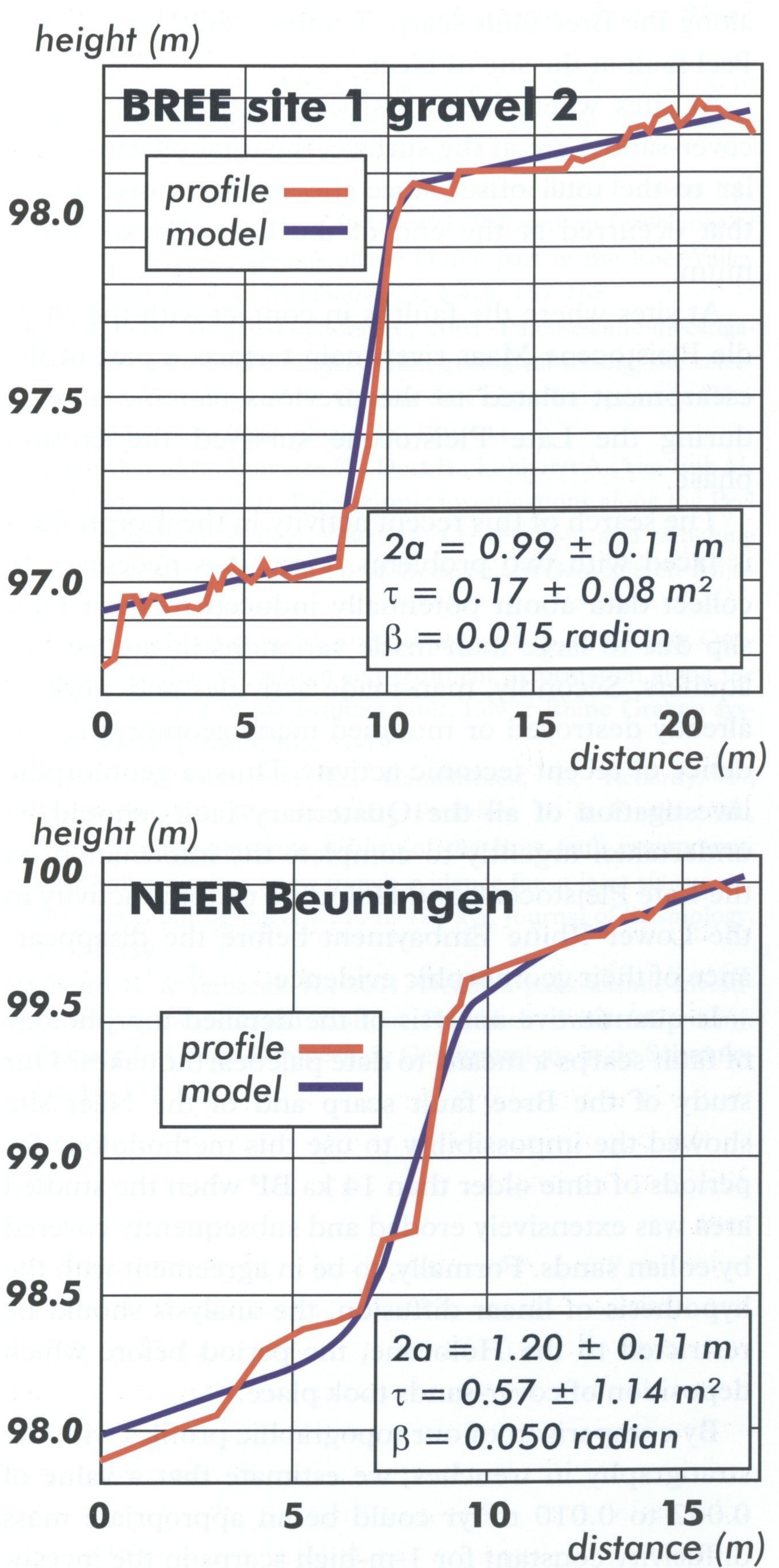

Fig. 8. Inversion of the profile corresponding to fault-displaced gravel layers inside trenches at Bree and Neer: gravel layer 1 (Beuningen gravel bed) in Bree trench 1 - displacement at the fault gravel layer 2 in Bree trench 1 - total displacement

Beuningen gravel bed inside Bree trench 4.

Beuningen gravel bed inside Neer trench (The Netherlands)

Cover-sand II and of Younger Cover-sand I and II (Kolstrup, 1980). Thus, formally, scarp degradation analyses can be used only to date scarps formed during the post glacial period.

The analysis of the Neer site across the Peel fault suggests that the vertical offset since the Last Glacial Maximum is $1.3 \mathrm{~m}$ (table 1 ). If the elevation profile of the Beuningen gravel bed inside the trench is corrected by this offset, a slope of 0.05 radians remains (fig. 8 ). In this absolutely flat landscape with a purely horizontal depositional environment (van den Berg,
1996), this is an indication of the existence of a scarp which was erased during the Last Glacial Maximum and thus of tectonic activity during the Pleniglacial period between $25 \mathrm{ka} \mathrm{BP}$ and $16 \mathrm{ka} \mathrm{BP}$.

\section{Discussion}

Fault activity in the Roer Graben since the Last Glacial Maximum is clearly evidenced in the morphology by small escarpments. The measured vertical topographic offset is respectively $\sim 1 \mathrm{~m}$ and $1.3 \mathrm{~m}$ 
along the Bree fault scarp (Feldbiss fault) and on the Peel fault at the site of Neer.

At sites where late Pleistocene sediments (mainly cover-sands) are at the surface, the total offset is similar to the total offset since the strong erosive phase that occurred at the end of the Last Glacial Maximum.

At sites where the fault is in contact with the Middle Pleistocene Maas river main terrace, a part of the escarpment related to the previous tectonic activity during the Late Pleistocene survived the erosion phase.

The search of this recent activity in the morphology is faced with two problems. First, it is necessary to collect data about potentially induced modern fault slip due to large man-made variations in the level of aquifers. Secondly, man-made activities and working already destroyed or modified many geomorphic evidence of recent tectonic activity. Thus, a geomorphic investigation of all the Quaternary faults should be undertaken urgently to complete the information on the Late Pleistocene and Holocene tectonic activity in the Lower Rhine Embayment before the disappearance of their geomorphic evidence.

Is quantitative analysis of the detailed morphology of fault scarps a means to date paleoearthquakes? Our study of the Bree fault scarp and of the Neer site showed the impossibility to use this methodology for periods of time older than $14 \mathrm{ka} \mathrm{BP}$ when the studied area was extensively eroded and subsequently covered by eolian sands. Formally, to be in agreement with the hypothesis of linear diffusion, the analysis should be restricted to the Holocene, the period before which deposition of cover-sands took place.

By comparison of our topographic profiles with the stratigraphy in trenches, we estimate that a value of 0.002 to $0.010 \mathrm{~m}^{2} / \mathrm{yr}$ could be an appropriate mass diffusivity constant for $1-\mathrm{m}$-high scarps in the investigated region.

This value is higher than the value $\left(0.0015 \mathrm{~m}^{2} / \mathrm{yr}\right)$ calculated by Nivière and Marquis (2000) for a 1.6$\mathrm{m}$-high and 100 years old man-made scarp in the Upper Rhine Graben. The discrepancy can be explained by different factors. The scarp in the Upper Rhine Graben is an abandoned railway embankment characterised by a higher cohesion of the material; the initial slope angle is $41^{\circ}$ compared to $30^{\circ}-35^{\circ}$ in a natural environment with unconsolidated sediments. Its age is very young, implying that it did not experience exceptional climatic conditions which should have stronger influence on its degradation. It did not suffer from agricultural activities either.

As pointed out by Andrews and Bucknam (1987), it is necessary to use a nonlinear diffusion model to take into account the clear trend of apparent age increasing linearly with offset. Thus, to be able to apply morphologic dating, it is fundamental to estimate the variation of the diffusivity in function of the scarp offset. This work has to be done, for example by studying the recent scarps formed by the different terrace incisions of the Maas river since the Pleniglacial.

\section{Conclusion}

From our analysis of the active Bree fault in Belgium and of the Peel fault in the Netherlands, we conclude that in the Lower Rhine Embayment, fault scarps visible in the area where late Pleistocene sediments are deposited at the surface, are a clear indication of post Last Glacial Maximum activity (younger than $14 \mathrm{ka}$ $\mathrm{BP})$. For these scarps, scarp degradation modelling can be applied to estimate their vertical offset and age. The method is attractive because it is fast and non-destructive. Vertical offset estimation is relatively precise whereas age evaluation is more problematic because man-made perturbations modified or destroyed surface evidence of the very recent fault activity in many sites. For scarps corresponding to tectonic activity older than the Last Glacial Maximum, the modelling cannot be used.

\section{Acknowledgements}

This study is a part of PALEOSIS-project, an environment and climate project of the European Commission (contract ENV4-CT97-0578).

\section{References}

Ahorner, L., 1968. Erdbeben und jüngste tektonik im Braunkohlenrevier der Niederrheinischen Bucht. Z. Deutsch. Geol.Ges, 118, 150-160.

Ahorner, L., 1975. Present-day stress field and seismotectonic block movements along major fault zones in Central Europe. Tectonophysics, 29, 233-249.

Ahorner, L., 1997. How reliable are speculations about large paleoearthquakes at the western border fault of the Roer Valley Graben near Bree. Comptes Rendus of the 81 th JLG-meeting.

Andrews, D. J., Hanks, T. C. 1985. Scarp Degraded by Linear Diffusion : Inverse Solution for Age, Journal of Geophysical Research, Vol. 90, NO. B12, 10193-10208.

Andrews, D.J. and Bucknam R.C., 1987. Fitting degradation of shoreline scarps by a nonlinear diffusion model.

Beerten, K., Brabers P., Bosch P., and Gullentops F., 1999 - The passage of the Feldbiss Bundle through the Maas Valley. Aardkundige Mededelingen, 9 : 153-158.

Briquet, A. 1908. La Meuse en aval de Sittard. Bulletin de la Société Belge de Géologie, 25, 347-385.

Bucknam, R. C., Anderson, R. E., 1979. Estimation of Fault Scarp Ages from a Scarp-height-slope-angle Relationship, Geology, Vol. 7, 11-14.

Camelbeeck, T., and van Eck, T., 1994. The Roer Valley Graben 
earthquake of 13 April 1992 and its seismotectonic setting. Terra Nova, 6 : 291-300.

Camelbeeck, T., and Meghraoui, M., 1996 - Large earthquakes in northern Europe more likely than once thought. EOS, Transactions, $A G U, 77(42): 405,409$.

Camelbeeck, T. and Meghraoui, M., 1998. Geological and geophysical evidence for large palaeo-earthquakes with surface faulting in the Roer Graben (northwest Europe). Geophysical Journal International, 132, 347-362.

Demanet, D., Evers, L.G., Teerlynk, H., Dost, B. and Jongmans, D. Geophysical investigation along the Peel Boundary fault (The Netherlands) for a paleoseismological study. This volume.

Hanks, T. C., Andrews, D. J., 1989. Effect of the Far-Field Slope on Morphologic Dating of Scarplike Landforms. Journal of Geophysical Research, Vol. 94, NO. B1, 565-573.

Kolstrup, E., 1980. Climate and stratigraphy in northwestern Europe between 30,000 B.P. and 13,000 B.P., with special reference to the Netherlands. Mededelingen Rijks Geologische Dienst, 32(15), 181-253.

Lehman, K., Klostermann J., Pelzing R. and Hinzen K., 2001. Paleoseismic investigations at the Rurrand fault, FRG. Cahiers du Centre Européen de Géodynamique et de Séismologie, 18, 93-96.

Meghraoui M.., Camelbeeck T., Vanneste K., Brondeel M., and Jongmans D., 2000. Active faulting and paleoseismology along the Bree fault, Lower Rhine Graben (Belgium). Journal of Geophysical Research, 105, 13,809-13,841.

Nash, D.B., 1980. Morphologic dating of degraded normal fault scarps. Journal of Geology, 88, 353-360.

Niviere, B. and Marquis, G., 2000. Evolution of terrace risers along the upper Rhine graben inferred from morphologic dating methods: evidence of climatic and tectonic forcing. Geophysical Journal International, 141, 577-594.

Schaefer, W., 1999. Bodenbewegungen und Bergschadensre- gulierung im Rheinischen Braunkohlenrevier. Report Rheinbraun AG.

Van den Berg, M.W., 1996. Fluvial sequences of the Maas. A 10 $\mathrm{Ma}$ record of neotectonics and climate change at various timescales. Thesis University Wageningen, 181 pages.

Van den Berg, M.W., Groenewoud W., Lorenz G.K, Lubbers P.J., Brus D.J. \& Kroonenberg S.B., 1994. Patterns and velocities of recent crustal movements in the Dutch part of the Roer Valley rift system. Geol. en Mijnbouw, 73, 2-4, p. 157-168.

Van den Berg, M. and Lokhorst A., 2001. Paleoseismic investigations along the Peel boundary fault: geological setting, site selection and trenching results. Cahiers du Centre Européen de Géodynamique et de Séismologie, 18, 139-144.

Van den Berg, M.., Vanneste K., Dost B., Lokhorst A., Van Eijk M. and Verbeek K., 2001. Paleoseismic investigations along the Peel Boundary fault: geological setting, site selection and trenching results. Netherlands Journal of Geosciences/Geologie en Mijnbouw, 81, (1), 2002.

Vanneste, K., Meghraoui M. and Camelbeeck T., 1999. Late Quaternary earthquake-related soft-sediment deformation along the Belgian portion of the Feldbiss fault, Lower Rhine Graben system. Tectonophysics, 309, 57-79.

Vanneste, K., Verbeeck, K., Camelbeeck, T., Renardy, F., Meghraoui, M., Jongmans, D., Paulissen E. \& Frechen M., 2001. Surface rupturing history of the Bree fault escarpment, Roer Valley Graben : new trench evidence for at least six successive events during the last 150 to $185 \mathrm{kyr}$. Journal of Seismology, 5, 323-359.

Vanneste, K. \& Verbeeck, K., 2001. Detailed paleoseismic investigation of the Rurrand fault in Hambach trench, Germany. Cahiers du Centre Européen de Géodynamique et de Séismologie, $18,153-156$. 